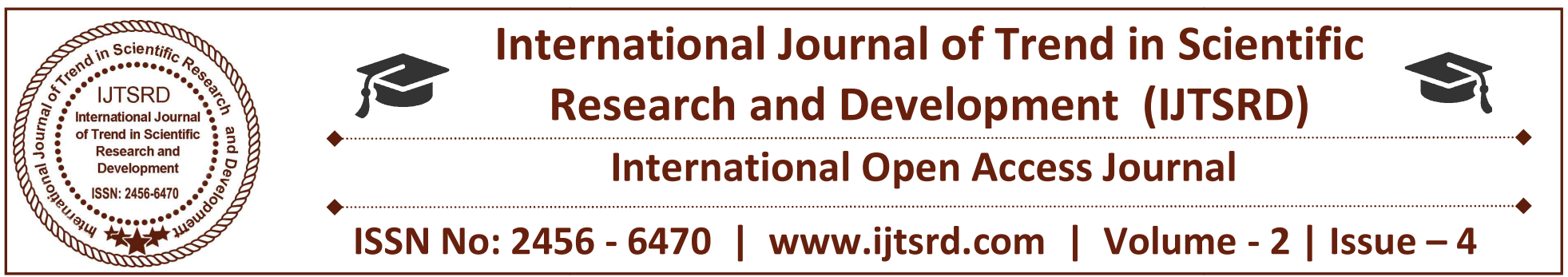

\title{
Evaluation of Dispersion Potential for Some Problem Soils in Central Myanmar
}

\author{
Khin Win Nwe, Nyan Myint Kyaw \\ Ph.D Candidate, Department of Civil Engineering, \\ Yangon Technological University, \\ The Republic of the Union of Myanmar, Yangon, Myanmar
}

\begin{abstract}
Dispersive soils which occur in central region of Myanmar are easily erodible and serious problem of stability of embankments, earth dams, earths and earth retaining structures. These soils are found in regions where the annual rainfall is less than $800 \mathrm{~mm}$. Dispersive soil is structurally unstable and the presence of dispersive soil is indicated by occurrence of erosion gullies, sink holes, spew holes and piping. In some parts of the central Myanmar, dispersive soils have to be used for construction purpose since no other soil material is available. Dispersion only occurs in non-saline or rain water. If dispersive soils have been used in the construction of earth-dams and embankments, serious piping and failures are occurred. In Myanmar, some problems are found in central region of Myanmar. The study soil is investigated by emersion test in field and then physical tests are done in Yangon Technological University and chemical tests are done in Irrigation and Management of Water Utilization Department in Myanmar. According to these tests results, most of the study soils are dispersive. This paper presents the results of study soils, soil structural problems along Yangon-Mandalay Express Way, dispersive potential rating for the study soils and the correlation between Exchangeable sodium percentage (ESP) and Atterberg's limits.
\end{abstract}

Keywords: Atterberg's Limit Test, Exchangeable sodium percentage (ESP), Cation exchange capacity (CEC)

\section{INTRODUCTION}

Many earth dams, hydraulic structures and other structures like road way embankments have suffered serious erosion problems and have failed due to the presence of the dispersive soils. Though the problem has been identified in many parts of the world in recent times, design advances and technical preventive measures are yet to be fully developed and practiced. As the scope and magnitude of the problem which can result from the use of dispersive soil is very high, preventing the failures caused by the dispersibility of the soils has become one of the major concerns of the geotechnical engineers.

In the past, clay soils were considered to be highly resistant to erosion by flowing water, however, in the last few years it was recognized that highly erodible clay soils exist in nature. The tendency for dispersive erosion in a given soil depends on variables such as mineralogy and chemistry of the clay, as well as dissolved salts in the water in soil pores and in the eroding water. Such clays are eroded rapidly by slowmoving water, even when compared to cohesionless fine sands and silts. When dispersive clay soil is immersed in water, the clay fraction behaves like single-grained particles; that is, the clay particles have a minimum of electrochemical attraction and fail to closely adhere to, or bond with, other soil particles. Thus, dispersive clay soil erodes in the presence of flowing water when individual clay platelets are split off and carried away. Such erosion may start in a drying crack, settlement crack, hydraulic fracture crack, or other channel of high permeability in a soil mass. Dispersive soils are clayey and silty soils which 
are highly susceptible to erosion. The dispersion occurs when the repulsive forces between individual clay particles exceed the attractive forces (Vander Waals attraction) so that when the clay mass is even in contact with still water individual clay particles are progressively detached from the surface $\&$ go into suspension.

The principal difference between dispersive clays and ordinary erosion resistant clays appears to be the nature of the cations in the pore water of the clay mass. Dispersive clays have a preponderance of sodium cations, whereas ordinary clays have a preponderance of calcium, potassium, and magnesium cations in the pore water.

\section{PROBLEMS DUE TO DISPERSIVE SOIL IN STUDY AREA}

The problems related to dispersive soils are common throughout the world. In Myanmar, some of the problems due to dispersive soil are occurred in central region of Myanmar and on the Yangon-Mandalay Express Way embankment. In the past, clay soils were considered to be highly resistant to erosion by flowing water, however, in the last few years it is recognized that highly erodible clay soils exist in nature. Some natural clay soils are dispersed or deflocculated in the presence of relatively pure water and are, therefore, highly susceptible to erosion and piping. Piping failure in embankment is caused by water flowing through the pores of the soil. The erosion occurs mainly in cohesionless soils which have little resistance to the plucking forces of seeping water. With dispersive clay, piping is due to a deflocculating process where water travels through a concentrated leakage channel then occurs along the entire length at the same. Erosion damage in embankments constructed with dispersive soils have generally occurred in areas of high crack potential such as long conduits, in areas of large differences in compressibility of foundation materials. When a concentrated leak starts through embankment constructed of dispersive clay, either of falling two actions may occur: (a) .If the velocity is sufficiently low, the clay surrounding the flow channel swells and progressively seals off the leak. (b) If the initial velocity is sufficiently rapid, the dispersed clay particles are carried away, enlarging the flow channel at faster channel at faster rate than it is closes by swelling leading to progressive piping failure. Some of the failures due to dispersive soil on Yangon-
Mandalay Express Way embankment are shown in Figure (1), (2) and (3).

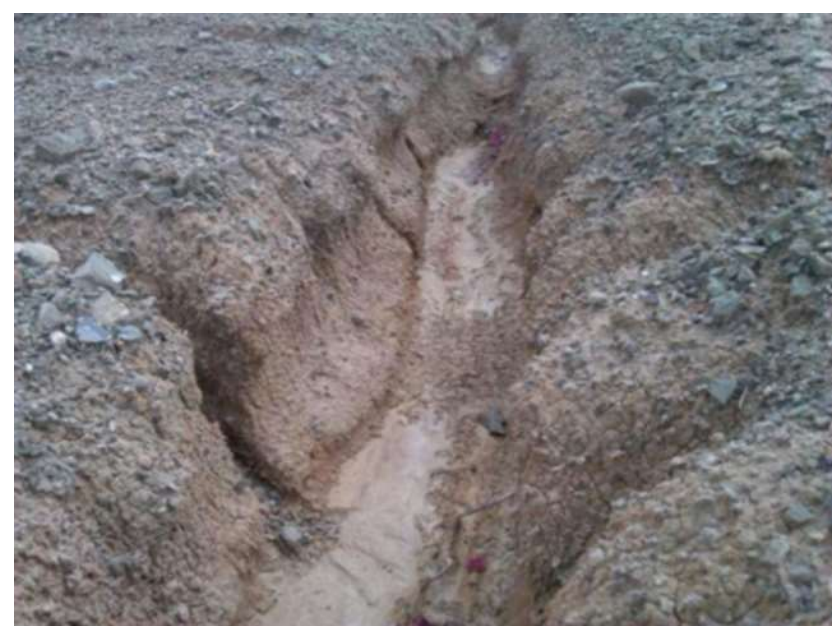

Figure 1 Channel Erosion

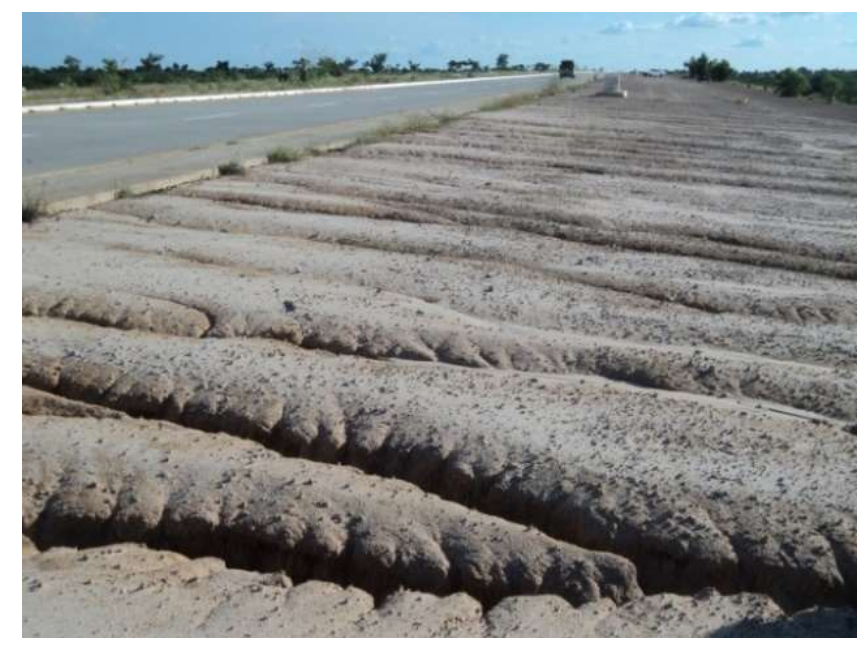

Figure 2 Channel and Piping Erosion

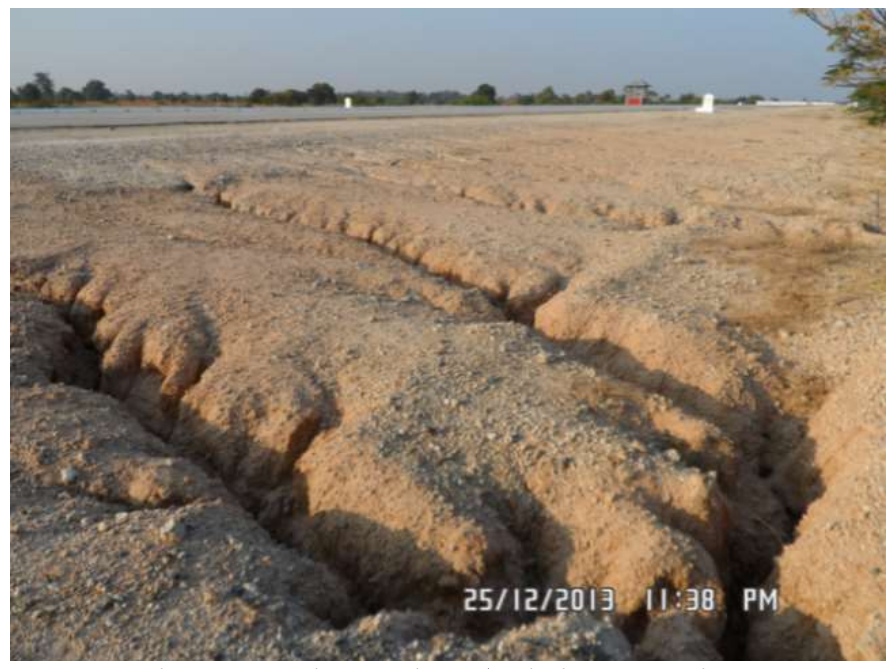

Figure 3 Channel and Piping Erosion 


\section{III.METHODOLOGY}

The flow chart for the study plan is as shown in the Figure (4)

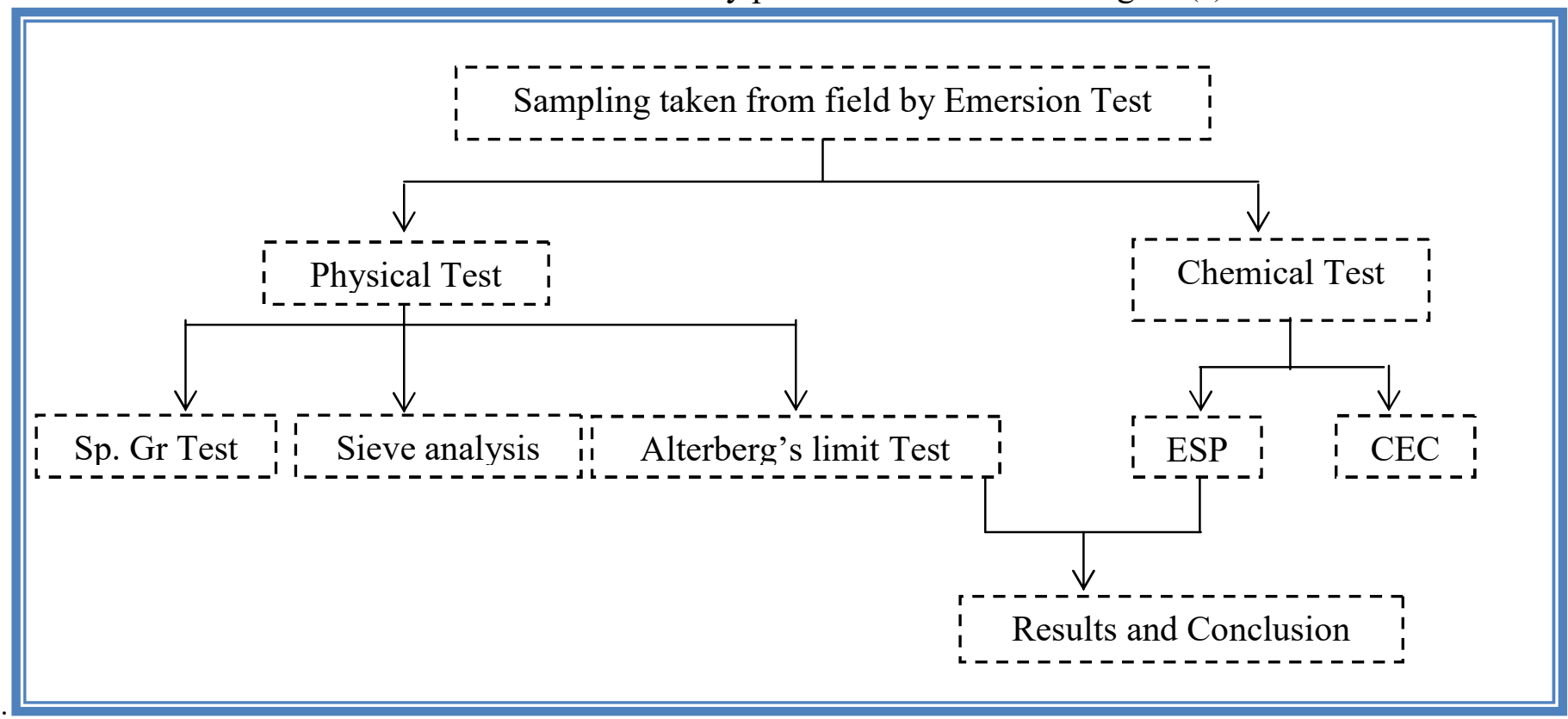

Figure 4 Flow Chart of the Study Plan

1. Exchangeable Sodium Percent (ESP)

The Exchangeable Sodium Percent (ESP)is the most common analytical technique used to identify sodic or dispersive soils. The ESP is determined from the ratio of exchangeable cations

$$
\operatorname{ESP}(\%)=\frac{N a^{+}}{N a^{+}+M g^{2+}+K^{+}+C a^{2+}} \times 100
$$

Table1. Relationship between degree of dispersion and percentage of exchangeable sodium

\begin{tabular}{|c|c|}
\hline $\begin{array}{c}\text { Exchangeable Sodium } \\
\text { Percentage (ESP) }\end{array}$ & Rating \\
\hline$<6$ & Non-sodic \\
\hline $6-10$ & Slightly sodic \\
\hline $10-15$ & Moderately sodic \\
\hline$>15$ & Highly sodic \\
\hline
\end{tabular}

\section{Cation Exchange Capacity(CEC)}

$\mathrm{CEC}$ is the number of positive charges(cations)that a representative sample of soil can hole. It is usually described as the number of hydrogen ions $\left(\mathrm{H}^{+}\right)$ necessary to fill the soil cation holding sites per 100 grams of drysoil. Alternatively equivalent amount of another cation $\left(\mathrm{Al3}^{+} \mathrm{Ca}^{2+}\right)$ can be used in the measured.CEC expressed as centimoles of positive charge per kilogram of $\operatorname{soil}(\operatorname{cmol}(+) / \mathrm{kg})$ or $\mathrm{meq} / 100 \mathrm{~g}$ (milli-equivalent/100g of soil).

\section{Identification of Dispersive Soil by Emerson Field Test}

Field testing is able to identify dispersive soils by observing the behaviour of air dried aggregates soil samples in distilled water or rainwater. The Emerson crumb test is used as an initial test to identify dispersive soil in the field.

Step 1 Collect soil aggregates ( 2 or 3 pea sized soil aggregates / 1-2cm in diameter) from each layer in the soil profile representative of the soil layers.

Step 2 If moist, dry the aggregates in the sun for a few hours until air-dried (Note: aggregates may not disperse when they should if they have not been sufficiently dried).

Step 3 Gently place the selected aggregates in a shallow glass or jar of distilled water or rain water.

Step 4 Leave the soil aggregates on a stable surface without shaking or disturbing them for 2 hours.

Step 5 Record the results to determine the level of dispersion observed (refer to Figure (5)) 


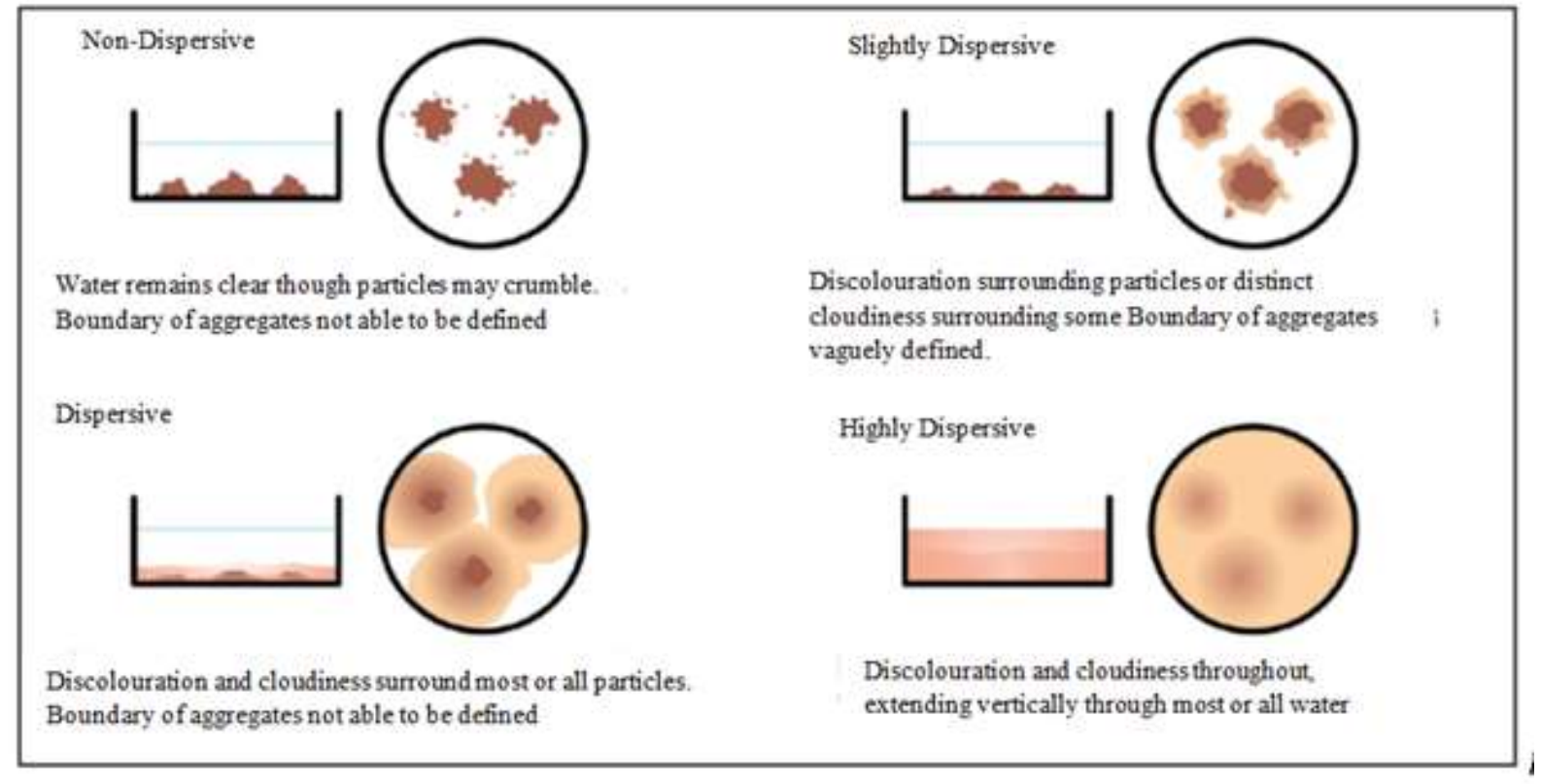

Figure 5 Emerson Field Test

4. Classification of Study Soil by USCS

The study soils are classified by Unified Soil Classification System and the results are shown in Table (2).

Table2. Soil Sample Classification

\begin{tabular}{|c|c|c|c|c|c|c|c|c|}
\hline Sample no. & $\begin{array}{c}\% \text { of } \\
\text { sand }\end{array}$ & $\begin{array}{c}\% \text { of } \\
\text { silt }\end{array}$ & $\begin{array}{c}\% \text { of } \\
\text { clay }\end{array}$ & $\begin{array}{c}\text { Plastic } \\
\text { Limit } \%\end{array}$ & $\begin{array}{c}\text { Liquid } \\
\text { Limit } \%\end{array}$ & $\begin{array}{c}\text { Plasticity } \\
\text { Index (\%) }\end{array}$ & $\begin{array}{c}\text { Specific } \\
\text { Gravity }\end{array}$ & $\begin{array}{c}\text { Type of soil } \\
\text { by USCS }\end{array}$ \\
\hline 1 & 59 & 11.5 & 29.5 & 13 & 20 & 7 & 2.69 & SC \\
\hline 2 & 45 & 11.5 & 43.5 & 10 & 33 & 23 & 2.64 & CL \\
\hline 3 & 49 & 23 & 28 & 17 & 33 & 16 & 2.67 & CL \\
\hline 4 & 52 & 8.5 & 39.5 & 14 & 30 & 16 & 2.6 & SC \\
\hline 5 & 15 & 20 & 65 & 10 & 29 & 19 & 2.65 & CL \\
\hline 6 & 43 & 10 & 47 & 20 & 61 & 41 & 2.68 & CH \\
\hline 7 & 49 & 11.5 & 39.5 & 18 & 40 & 22 & 2.67 & CL \\
\hline 8 & 55.5 & 5 & 39.5 & 23 & 59 & 36 & 2.66 & CH \\
\hline 9 & 79 & 1.5 & 19.5 & 11 & 24 & 13 & 2.64 & SC \\
\hline 10 & 29 & 21.5 & 49.5 & 25 & 102 & 77 & 2.58 & CH \\
\hline 11 & 29 & 11.5 & 59.5 & 20 & 63 & 43 & 2.8 & CH \\
\hline 12 & 43.5 & 11.5 & 45 & 20 & 52 & 32 & 2.79 & CH \\
\hline 13 & 57 & 10 & 33 & 13 & 39 & 26 & 2.64 & SC \\
\hline 14 & 40.5 & 20 & 39.5 & 12 & 35 & 23 & 2.7 & CL \\
\hline
\end{tabular}


International Journal of Trend in Scientific Research and Development (IJTSRD) ISSN: 2456-6470

\begin{tabular}{|c|c|c|c|c|c|c|c|c|}
\hline Sample no. & $\begin{array}{l}\% \text { of } \\
\text { sand }\end{array}$ & $\begin{array}{l}\% \text { of } \\
\text { silt }\end{array}$ & $\begin{array}{l}\% \text { of } \\
\text { clay }\end{array}$ & $\begin{array}{c}\text { Plastic } \\
\text { Limit (\%) }\end{array}$ & $\begin{array}{l}\text { Liquid } \\
\text { Limit (\%) }\end{array}$ & $\begin{array}{l}\text { Plasticity } \\
\text { Index (\%) }\end{array}$ & $\begin{array}{l}\text { Specific } \\
\text { Gravity }\end{array}$ & $\begin{array}{c}\text { Type of soil } \\
\text { by USCS }\end{array}$ \\
\hline 16 & 74 & 6.5 & 19.5 & 19 & 48 & 29 & 2.66 & $\mathrm{SC}$ \\
\hline 17 & 60 & 5 & 35 & 18 & 45 & 27 & 2.78 & $\mathrm{SC}$ \\
\hline 18 & 44 & 6.5 & 49.5 & 20 & 57 & 37 & 2.53 & $\mathrm{CH}$ \\
\hline 19 & 43 & 2 & 55 & 16 & 37 & 21 & 2.7 & $\mathrm{CL}$ \\
\hline 20 & 41 & 2 & 57 & 15 & 56 & 41 & 2.59 & $\mathrm{CH}$ \\
\hline 21 & 38 & 2 & 60 & 21.3 & 38 & 16.7 & 2.61 & $\mathrm{CL}$ \\
\hline 22 & 38 & 2 & 60 & 13 & 45 & 32 & 2.68 & $\mathrm{CH}$ \\
\hline 23 & 44 & 2 & 54 & 15 & 33 & 18 & 2.65 & $\mathrm{CL}$ \\
\hline 24 & 39 & 2 & 59 & 16 & 37 & 21 & 2.63 & $\mathrm{CL}$ \\
\hline 25 & 42 & 2 & 56 & 17 & 51 & 34 & 2.71 & $\mathrm{CH}$ \\
\hline 26 & 42 & 2 & 56 & 16 & 50 & 34 & 2.67 & $\mathrm{CH}$ \\
\hline 27 & 40 & 2 & 58 & 13 & 55 & 42 & 2.69 & $\mathrm{CH}$ \\
\hline 28 & 40 & 2 & 58 & 13 & 50 & 37 & 2.69 & $\mathrm{CH}$ \\
\hline 29 & 43 & 2 & 55 & 18 & 61 & 43 & 2.64 & $\mathrm{CH}$ \\
\hline 30 & 67 & 12 & 21 & 22 & 42 & 20 & 2.75 & $\mathrm{SC}$ \\
\hline 31 & 62 & 15.5 & 22.5 & 24 & 51 & 27 & 2.8 & $\mathrm{SC}$ \\
\hline 32 & 17 & 34 & 49 & 40 & 19 & 21 & 2.73 & $\mathrm{CL}$ \\
\hline 33 & 22 & 27 & 51 & 46 & 23.5 & 22.5 & 2.69 & $\mathrm{CL}$ \\
\hline
\end{tabular}

Specific gravity for study soils are between 2.53 to 2.8 .

Minimum liquid limit is $20 \%$ and maximum is $102 \%$.

Minimum plasticity index is $7 \%$ and maximum is $77 \%$.

Therefore dispersive soils are low to high plasticity.

Most of the study soils are CL, CH and SC.

5. Analytical Data for Soil Sample

Dispersive rating for study soils are classified by chemical tests and these results are shown in Table 3.

Table3. Analytical Data for Soil Sample

\begin{tabular}{|c|c|c|c|c|c|}
\hline Sample No & pH & CEC $(\mathrm{cmol} / \mathrm{kg})$ & ESP $(\%)$ & Rating & Remark \\
\hline 1 & 8.2 & 15.78 & 26.43 & Highly Sodic & Dispersive \\
\hline 2 & 9.1 & 30.44 & 20.57 & Highly Sodic & Dispersive \\
\hline 3 & 8.4 & 47.84 & 6.54 & Slightly Sodic & Margin \\
\hline 4 & 8.1 & 42.44 & 9.87 & Slightly Sodic & Dispersive \\
\hline 5 & 8.6 & 21.12 & 35.42 & Highly Sodic & Dispersive \\
\hline 6 & 8.9 & 19.49 & 38.38 & Highly Sodic & Dispersive \\
\hline
\end{tabular}


International Journal of Trend in Scientific Research and Development (IJTSRD) ISSN: 2456-6470

\begin{tabular}{|c|c|c|c|c|c|}
\hline Sample No & $\mathrm{pH}$ & CEC (cmol/kg) & $\operatorname{ESP}(\%)$ & Rating & Remark \\
\hline 7 & 8.9 & 20.5 & 34.34 & Highly Sodic & Dispersive \\
\hline 8 & 9.7 & 18.44 & 13.67 & Moderately Sodic & Dispersive \\
\hline 9 & 8.7 & 10.73 & 26.28 & Highly Sodic & Dispersive \\
\hline 10 & 9.1 & 13.42 & 62.59 & Highly Sodic & Dispersive \\
\hline 11 & 8.9 & 16.15 & 53.87 & Highly Sodic & Dispersive \\
\hline 12 & 8.8 & 30.66 & 18.17 & Highly Sodic & Dispersive \\
\hline 13 & 9.0 & 14.59 & 34.82 & Highly Sodic & Dispersive \\
\hline 14 & 8.8 & 17.43 & 35.92 & Highly Sodic & Dispersive \\
\hline 15 & 8.7 & 17.92 & 37.17 & Highly Sodic & Dispersive \\
\hline 16 & 8.8 & 19.27 & 24.39 & Highly Sodic & Dispersive \\
\hline 17 & 8.8 & 16.65 & 30.51 & Highly Sodic & Dispersive \\
\hline 18 & 8.8 & 20.33 & 34.88 & Highly Sodic & Dispersive \\
\hline 19 & 8.9 & 12.03 & 15.88 & Highly Sodic & Dispersive \\
\hline 20 & 9.0 & 11.55 & 24.85 & Highly Sodic & Dispersive \\
\hline 21 & 9.4 & 12.11 & 20.07 & Highly Sodic & Dispersive \\
\hline 22 & 9.0 & 18.17 & 15.30 & Highly Sodic & Dispersive \\
\hline 23 & 8.8 & 19.68 & 16.36 & Highly Sodic & Dispersive \\
\hline 24 & 9.2 & 13.99 & 15.51 & Highly Sodic & Dispersive \\
\hline 25 & 9.2 & 35.54 & 40.6 & Highly Sodic & Dispersive \\
\hline 26 & 8.8 & 19.78 & 10.11 & Moderately Sodic & Dispersive \\
\hline 27 & 8.9 & 12.45 & 16.87 & Highly Sodic & Dispersive \\
\hline 28 & 9.3 & 11.33 & 25.33 & Highly Sodic & Dispersive \\
\hline 29 & 9.0 & 11.76 & 17.01 & Highly Sodic & Dispersive \\
\hline 30 & 8.25 & 14.17 & 35.51 & Highly Sodic & Dispersive \\
\hline 31 & 9.12 & 26.09 & 20.01 & Highly Sodic & Dispersive \\
\hline 32 & 8.2 & 29.27 & 8.17 & Slightly Sodic & Dispersive \\
\hline 33 & 7.57 & 16.09 & 30.83 & Highly Sodic & Dispersive \\
\hline
\end{tabular}

In study soils, $\mathrm{pH}$ values are between 7.57 and 9.4.But most of the soil samples of specific gravity is greater than 8 . From the analytical results, increasing $\mathrm{pH}$ with the number of negative charges on the colloids increases. So CEC also increases.pH greater than 8 indicates possible high levels of exchangeable sodium or magnesium, and therefore a tendency for the clay to disperse. 


\section{RESULTS AND DISCUSSION}

The relation between the Exchangeable sodium percentage and Liquid limit is calculated by SPSS software based on Linear Regression Analysis.

Where,

$$
\mathrm{ESP}=\mathrm{a}+\mathrm{b} \mathrm{LL}
$$

$$
\begin{aligned}
& \text { ESP }=\text { Exchangeable sodium percentage } \\
& \text { LL = Liquid limit } \\
& a=\text { constant } \\
& b=\text { the slope of the line }
\end{aligned}
$$

In mathematical modeling, $95 \%$ confidence interval is considered from thirty three samples and the following equation is obtained.

$$
\mathrm{ESP}=6.68+0.421 \mathrm{LL}
$$

The relationship curve for Exchangeable sodium percentage (ESP) and Liquid Limit (LL) is shown in Figure 6.

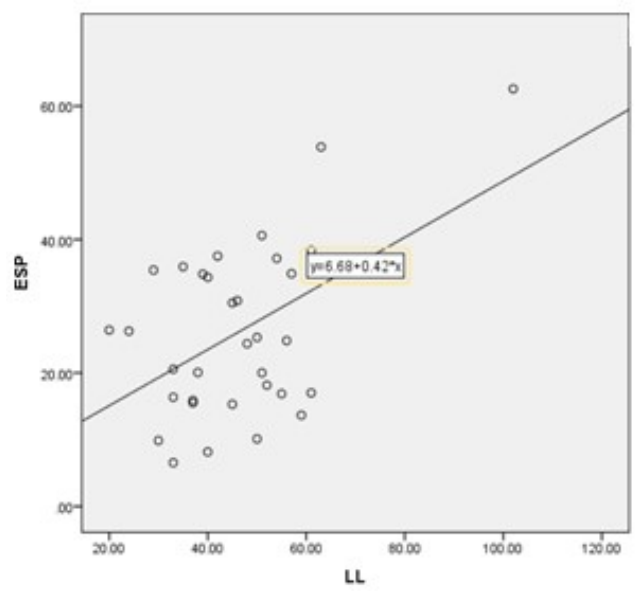

Figure 6 The Relationship Curve for ESP and LL

\section{CONCLUSION}

1. In this study, thirty three samples are collected from central region of Myanmar. All of the samples are tested in the laboratories from August to December, 2016.

2. According to the Alterberg's Limit test and sieve analysis results, the soil samples are $\mathrm{CH}, \mathrm{CL}$ and $\mathrm{SC}$ by Unified Soil Classification System.

3. According to the chemical test results, most of the soil samples of dispersive potential rating are high.

4. The observed behavior of the clays and the tests carried out demonstrate that the clays from these locations are dispersive and would not be suitable for use in embankment. This soil should be stabilized with lime or cement to be used for road construction
5. This problem is worldwide, and structural failures attributed to dispersive soils have occurred in many countries.

\section{ACKNOWLEDGMENT}

The authors extend their thanks to the technicians from Geotechnical Engineering Department, Yangon Technological University and Soil and Water Analytical Laboratory, Irrigation and Management of Water Utilization Department, Ministry of Agriculture, Livestock and Irrigation. The authors would like to thank all the persons who have helped towards the successful completion of this paper.

\section{REFERENCES}

1. Development of Guidelines for Construction and Development on Dispersive Soils. Marcus Harde TIAR, UTAS, DPIW, CSIRO

2. Dispersive soils and their Management

3. Farm note for identifying dispersive soil by Stephan Davis and Alison Lacey

4. ASTM 2000. ASTM 6572-00 Standard Test Method for Determining Dispersive Characteristics of Clayey Soils by Crumb Test

5. Gerber, FA \& Harmsem, HJ 1987. Proposed procedure to identific action of dispersive soils by chemical testing. The Civil Engineer in South Africa, 29(10):397-399

6. Umsha, T.S, Dinesh. S. V, Sivapullaiah. P. V. (2011) "Characterization of Dispersive Soils", Materials Sciences and Applications, 2, 629-633

7. Dixit, M. and Gupta. S. L, (2011) "Problems in characterization and identification of dispersive soils - a case study", International Journal of Earth Sciences and Engineering, ISSN 0974-5904, Volume 04, No 06 SPL, pp. 143-146

8. Hardie, M. (2009) " Dispersive Soil and their Management", Technical Refrence Manual, Sustainable Land Use Department of Primary Industries and Water

9. Mitchell, J. K. (1993) "Fundamentals of Soil Behavior," 2nd Edition, John Wiley \& Sons, Inc, Hoboken 